\title{
Longer sequence insertions in p6 gag play a role in immune escape in HIV-1 subtype C
}

\author{
Shilpee Sharma', GA Shambhu Prasad', Ravi Vijaya Satya ${ }^{2}$, Viswanath Ragupathy ${ }^{3}$, Shanmugam Saravanan ${ }^{4}$, \\ Kailapuri G Murugavel ${ }^{4}$, Pachamuthu Balakrishnan", Suniti Solomon ${ }^{4}$, Indira Hewlett ${ }^{3}$, Udaykumar Ranga ${ }^{*}$ \\ From 2nd International Science Symposium on HIV and Infectious Diseases (HIV SCIENCE 2014) \\ Chennai, India. 30 January - 1 February 2014
}

\section{Background}

HIV-1 is capable of evading the CTL immune response by introducing mutations in residues both within the epitopes and in sequences flanking the epitopes. The present study aims at identifying the mechanisms of CTL immune escape primarily in the asymptomatic phase of HIV-1 subtype $C$ in drug naive patients from an Indian clinical cohort.

\section{Methods}

In a prospective study, a cohort of select seropositive drug naive subjects is being monitored at YRG CARE, Chennai for a period of two years with repeated sampling at 6 -month intervals. The viral RNA was extracted from plasma and Gag was amplified, followed by Sanger sequencing. The samples of interest were further subjected to next-generation sequencing using Illumina MiSeq and analyzed using the CLC Genomics Workbench software.

\section{Results}

Twenty plasmid clones of gag were sequenced from one of the subjects at four different time-points. We observed multiple viral strains that did or did not contain an insertion of 14 amino acid residues in the PTAP domain of p6 gag. The PTAP duplication was further confirmed in 6 other subjects using the next- generation sequencing.

\section{Conclusion}

The preliminary data suggest that subtype $C$ is capable of causing sequence insertions of longer length in the PTAP domain of the p6 gag, unlike other viral subtypes that insert sequences of shorter length at this location.

\footnotetext{
* Correspondence: udaykumar@jncasr.ac.in

'Jawaharlal Nehru Centre for Advanced Scientific Research, HIV- AIDS

Laboratory, Bengaluru, India

Full list of author information is available at the end of the article
}

The bio informatics analysis is suggestive of the role of the amino acid insertions in immune escape in the chronic phase of the HIV-1 infection.

\begin{abstract}
Authors' details
'Jawaharlal Nehru Centre for Advanced Scientific Research, HIV- AIDS Laboratory, Bengaluru, India. ${ }^{2}$ Bioinformatics - Databases and Algorithm Development, Qiagen, MD, USA. ${ }^{3}$ Food and Drug Administration, Laboratory of Molecular Virology, Bethesda, MD 20892, USA. ${ }^{4}$ YRG Centre for AIDS Research and Education, Chennai, India.
\end{abstract}

Published: 27 May 2014

doi:10.1186/1471-2334-14-S3-E7

Cite this article as: Sharma et al.: Longer sequence insertions in p6 gag play a role in immune escape in HIV-1 subtype C. BMC Infectious Diseases 2014 14(Suppl 3):E7.
Submit your next manuscript to BioMed Central and take full advantage of:

- Convenient online submission

- Thorough peer review

- No space constraints or color figure charges

- Immediate publication on acceptance

- Inclusion in PubMed, CAS, Scopus and Google Scholar

- Research which is freely available for redistribution

Submit your manuscript at www.biomedcentral.com/submit
() Biomed Central 